\title{
Effect Of Rotor Blade Wing Tip On Wind Turbine Performance Using Naca 0018 Blade
}

\section{Pengaruh Wing Tip Sudu Rotor Blade Terhadap Unjuk Kerja Wind Turbin Dengan Menggunakan Blade Naca 0018}

\author{
Ibnu Mas'ud ${ }^{1}$, Rachmad Firdaus ${ }^{2}$ \\ \{ibnumasud2698@gmail.com ${ }^{1}$, firdausr@umsida.ac.id $\left.{ }^{2}\right\}$ \\ ${ }^{1,2}$ Fakultas Sains dan Teknologi. Universitas Muhammadiyah Sidoarjo, Indosesia
}

\begin{abstract}
Indonesia currently has a growing need for energy, this will experience an energy crisis, dependence on fossil fuels will at least have a serious threat, therefore there must be alternative energy as a substitute and reserve such as wind energy, water energy, solar energy, and other. This study aims to develop a wind power plant as an alternative source to produce electrical energy, namely a wind turbine. This tool is used to meet energy needs and also as an alternative energy so that fossil fuels will not run out. Because Indonesia is an archipelagic country and is located on the equator, Indonesia is a country that has abundant resources, one of which is wind. Wind turbine is a tool that functions to convert wind power into mechanical power in the form of a shaft rotation, this shaft rotation is then used for power generation or for water pumps. Therefore I tried to develop my ideas to utilize abundant natural resources to be used as a source of electrical energy by means of a wind turbine using a Naca 0018 blade. This study aims to determine the effect of the number of blades, the effect of profiles, the effect of the wing tip of the rotor blades. , naca 0018, and the resulting energy efficiency. This study uses the type of experimental research.
\end{abstract}

Keywords - wind turbin, $1 \mathrm{~mm}$ aluminium, naca 0018, performance experimental test

\begin{abstract}
Abstrak Indonesia saat ini mempunyai kebutuhan energi yang semakin besar hal ini akan mengalami kondisi krisis energi, ketergantungan terhadap bahan bakar fosil setidaknya akan memiliki ancaman yang serius, oleh karena itu harus ada energi alternative sebagai pengganti dan cadangan seperti energi angin, energi air, energi surya, dan lainya. Penelitian ini bertujuan untuk mengembangkan pembangkit listrik tenaga angin sebagai sumber alternative untuk menghasilkan energi listrik yaitu wind turbin. Alat ini dimanfaatkan untuk memenuhi kebutuhan energi dan juga sebagai energi alternative supaya bahan bakar fosil tidak akan habis. Dikarnakan Indonesia merupakan negara kepulauan dan terletak di garis khatulistiwa maka Indonesia adalah negara yang memiliki sumber daya yang melimpah salah satunya sumber angin. Turbin angin adalah alat yang berfungsi untuk mengubah daya angina menjadi daya mekanik dalam bentuk putaran poros, putaran poros ini selanjutnya dimanfaatkan untuk pembangkit listrik atau untuk pompa air. Maka dari itu saya mencoba untuk mengembangkan ide gagasan saya untuk memanfaatkan sumber daya alam yang melimpah untuk dijadikan sumber energi listrik dengan alat wind turbin dengan menggunakan blade naca 0018. pada penelitian ini bertujuan untuk mengetaahui pengaruh jumlah blade, pengaruh profil, pengaruh wing tip sudu rotor, naca 0018, dan efisiensi energi yang dihasilkan. Penelitian ini menggunakan jenis penelitian eksperimen.
\end{abstract}

Kata Kunci - kincir angin, aluminium $1 \mathrm{~mm}$, naca 0018, uji eksperimen performa

\section{Pendahuluan}

Pentingya kebutuhan energi di kehidupan manusia, menjadikan suatu hal yang tidak bisa terlepaskan dalam aktifitas sehari hari, begitupun juga energi listrik. Ketergantungan manusia dengan energi listrik memang tidak bisa di pisahkan. Populasi manusia yang terus berkembang pesat menjadikan kebutuhan energi listrik semakin meningkat, dengan prediksi populasi manusia pada tahun yang akan mendatang yaitu tahun 2050 kedepan akan meningkatnya populasi manusia menjadi 9 (sembilan) miliyar dari angka 7 (tujuh) miliyar pada awal abad 21.

Peningkatan kebutuhan listrik bagi kehidupan sehari hari sudah terlihat jelas, yang pertama berasal dari rumah rumah warga, yg kedua dari usaha kecil menengah atau para penduduk yang memenuhi kebutuhanya dengan cara berbisnis (home industri), yang ketiga merupakan instansi atau perusahaan yang membutuhkan energi listrik yang begitu besar yang digunakan untuk mengoprasikan beberapa kinerja industrinya termasuk jalanya mesin produksi dan lain lain. Diketahui kebutuhan listrik di tanah jawa dari tahun yang lalu ada sekitar 69,96 Twh pada tahun 2013, sekarang pada tahun 2020 yang di ketahui tanah jawa merupakan kawasan industry terbesar di Indonesia sehingga 
energi yang dibutuhkan semakin meninggkat menjadi 203,19 Twh. Itulah mengapa Indonesia harus mempunyai sumber energi yang terbarukan sehingga akan membantu pengurangan sumber energi listrik.

Di sisi lain kebutuhan energi listrik yang semakin banyak atau meningkat persediaan listrik di Indonesia menjadikan semakin tipisnya pasokan energi listrik, masalah lain akhir akhir ini sempat terjadi permasalahan yang serius yaitu krisis energi listrik di Indonesia. Belum lagi persebaran listrik di Indonesia yang belum merata di bagian pelosok hanya bagian di kota saja yang sudah menggunakan listrik. Permasalahan bukan itu saja masih ada permasalahan yg sering kita temui, diketahui persediaan energi listrik di Indonesia semakin menipis. Salah satu upaya untuk penghematan listrik dengan memadamkan energi listrik di daerah-daerah secara bergilir dengan tujuan pasok listrik di Indonesia tidak cepat habis dan masih tersedia pasokan lagi.

Diketahui Indonesia memiliki potensi dengan sumber daya alam yang melimpah yang bisa digunakanan dalam pengelolahan pembangkit listrik yaitu sungai, waduk, batu bara, dan udara. Berdasarkan sumber daya alam yang dapat berpotensi sebagai bahan utama pembangkit listrik, maka perlu dilakukan pemanfaatan sumber daya alam untuk menyelesaikan masalah ketersediaan listrik. Oleh karena itu, diperlukan ide dan gagasan untuk membahas dan menganalisis pengaruh wing tipe sudu rotor blade terhadap unjuk kerja water turbin dengan menggunakan blade naca 0018. Hal ini bertujuan untuk langkah awal menciptakan alat pembangkit listrik tenaga angin dengan menggunakan blade naca 0018. Turbin angin merupakan mesin dengan sudu berputar yang mengonversikan energi kinetic menjadi mekanik. Jika energi mekanik digunakan langsung secara permesinan seperti pompa atau grinding stones, maka mesin (turbin) disebut windmill. Jika energi mekanik dikonversikan menjadi listrik, makamesin disebut turbin atau wind energy converter (WEC).

\section{METODE}

Data yang diambil dalam pengujian eksperimental performance ini adalah untuk mengukur daya tegangan arus pada beban win turbin, dan juga mengetahui perbandingan performa turbin angin dengan menggunakan pengaruh variasai wing tip, mula mula pengujian kincir angin normal tanpa ada penambahan variasi eing tip selanjutnya dengan memberikan variasi wing tip di setiap ujung blade, total wing tip yang di pasang pada blade ada 8 wing tip, di setiap blade terdapat 2 wing tipe. Pengujian dan pengambilan data di lakukan dengan menggunakan tacho meter yang di uji di tanah lapang atau pesisir pantai yang memiliki cukup hembusan angina yang kuat.

Pada metode penelitian ini di awali dari langkah langkah persiapan material dan rancangan yang akan digunakan pada penelitian selanjutnya. Bahan yang di gunakan adalah aluminium plate ketebalan $1 \mathrm{~mm}$ yang digunakan sebagai daun airfoil naca 0018 , aluminium ketebalan $0,6 \mathrm{~mm}$ yang di gunakan sebagai lapisan atau casing dari airfoil tersebut hingga menjadi satu keutuhan yg di sebut blade, pipa aluminium out diameter $12 \mathrm{~mm}$ dan in diameter $10 \mathrm{~mm}$ sebanyak 12 pipa dengan panjang $40 \mathrm{~cm}$ yang digunakan sebagai arm, pipa aluminium out diameter $14 \mathrm{~mm}$ dan in diameter 12 mm sebanyak 1 pipa dengan panjang 1 yang digunakan sebagai poros kincir angin. Setelah material yang di butuhkan sudah terpenuhi selanjutnya aluminium plate ket $1 \mathrm{~mm}$ di bentuk sedemikian rupa menjadi daun airfoil naca 0018 kemudian 3 airfoil di kaitkan menjadi satu bagian dengan kerangka, lalu di beri lapisan plate dgn ketebalan 0,6 secara presisi sehingga menjadi blade, selanjutnya blate tersebut di beri penggubung arm penggunakan pipa $12 \times 10 \mathrm{yg}$ menghubungkan blade dengan poros dengan bantuan arm setelah itu jadilah kicir air yang nantinya akan di gunakan dalam penelitian ini.

Adapun pengujian dan pengambilan data yang akan dilakukan yaitu :

Pengujian A merupakan pengujian dan pengambilan data yang pertama di mana variasi wing tip belum terpasang pada masing - masing balde, yang nantinya data hasil pengujian ditampilkan dalam bentuk tabel dan grafik.

Pengujian B merupakan pengujian dan pengambilan data yang kedua di manapada variasi wing tip akan di pasang masing - masing blade, yang nantinya data hasil pengujian ditampilkan dalam bentuk tabel dan grafik. 


\section{Hasil dan Pembahasan}

Pengujian eksperimen ini adalah untuk mengetahui daya tegangan yang dihasilkan arus listrik pada kincir angin pada beban win turbin yang datanya di peroleh dari pengujian kincir angin tanpa ada variasi wing tip dan pengujian menggunakan variasi wing tip pada setiap blade tersebut. Sehingga dapat di peroleh hasil yang akan di bandingkan dan di simpulkan antara kincir angin tanpa adanya penambahan variasi wing tip, dengan adanya penambahan variasi wing tip manakah hasil yang lebih optimal. Pengujian dilakukan menggunakan alat tacho meter dan Volt meter yang nantinya akan di lakukan pengujian di tepi pantai tlocor.

\section{Proses Pembuatan Dan Perakitan}

Dibawah ini adalah langkah pembuatan sekaligus perakitan dari material aluminium plate yang di bentuk airfoil menjadi sebuah kincir air yang menghasilkan sebuah arus listrik sebagai berikut:

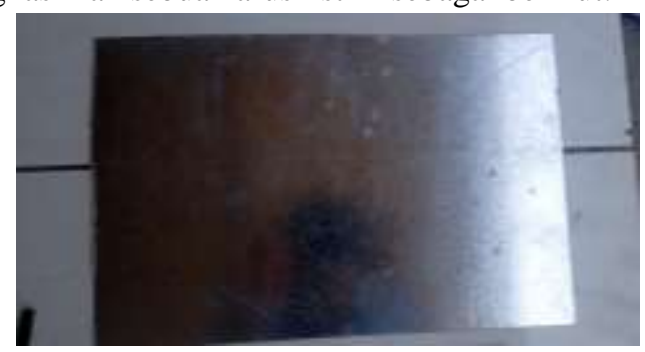

Gambar 4.1 aluminium

Dikarnakan penelitian yang digunakan menggunakan media air maka pemilihan material menggunakan bahan yang ringan, disini menggunakan bahan aluminium dengan ketebalan $1 \mathrm{~mm}$ yang nantinya digunakan sebagai pembuatan airfoil naca 0018 .

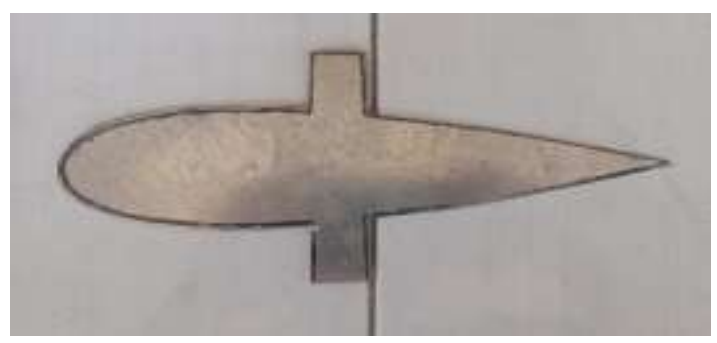

Gambar 4.2 airfoil naca 0018

Selanjutnya material tersebut di potong dan di bentuk menjadi airfoil naca 0018 yang nantinya di gunakan sebagai komponen paling penting.

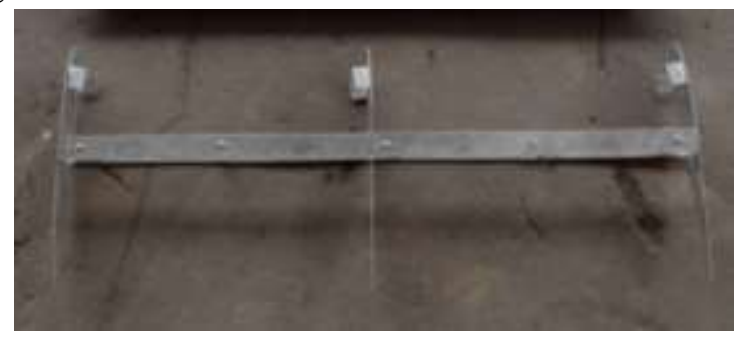

Gambar 4.3 kerangka blade

Setelah material di bentuk menjadi airfoil selanjutnya kombinasikan daun airfoil tersebut sebanyak 3 bagian yaitu sebelah kanan tengah dan kiri dengan memberikan plate sebagai kerangka, dengan tujuan supaya saat pemberian lapisan terdapat pijakan atau kedudukan sehingga lebih kuat dan presisi.

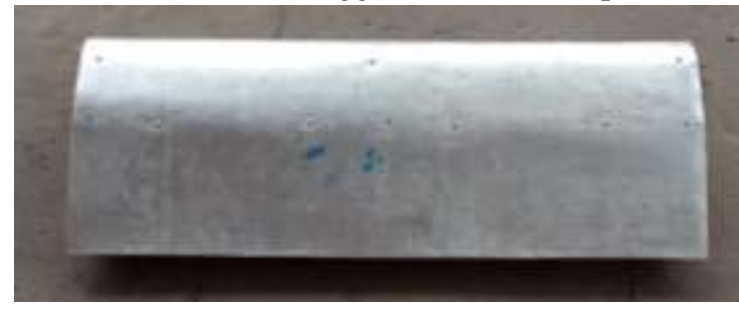


Gambar 4.4 blade naca 0018

Kemudian setelah proses penggabungan airfol dengan kerangka selesai, tahapan selanjutnya adalah memberikan lapisan aluminium plate dengan ketebalan 0,6 mm dengan cara di lapisi secara menyeluruh kemudian di rivet sebagai pengunci.

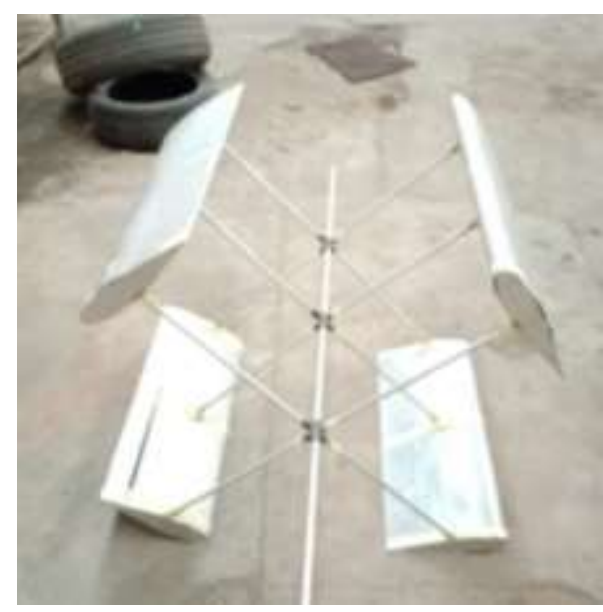

Gambar 4.5 kincir angin

Selanjutnya setelah pemberian lapisan atau casing selesai menjadi blade, kemudian berikan arm dengan ukureran pipa $12 \times 10$, kaitkan blade satu dengan satunya sampai menjadi 4 bagian yang terhubung beserta porosnya.

\section{Siklus Kerja Turbin angin}

Turbin angin merupakan seperangkat teknologi yang mengubah energi angin menjadi energi listrik dalam system pembangkit listrik tenaga bayu (PLTB), prinsip kerjanya sangat sederhana dan ringkas yaitu turbin angina memiliki beberapa bagian inti yakni bilah atau blade, poros, generator, dan tiang penyangga. European wind energy association (EWEA), turbin angina merubah energi kinetic yang dimiliki energi angina manjadi energi mekanik. Energi kinetic dari angina akan menabrak bilah turbin angina sehingga bilah akan berputar membuat porosnya berotasi, rotasi inilah yang nantinya menggerakkan generator dan menghasilkan listrik.

Siklus kerja dari turbin angina adalah pada saat bila beara di posisi yang tepat dimana mendapatkan hembusan angin yang cukup maka bilah atau blade akan berputar,selanjutnya putaran akan di teruskan ke poros, poros ke puly, puly ke fanbelt ,fan belt ke puly generator, kemudian generator ke inverter.

\section{Uji performa variasi wing tip}

Pada Uji performa ini merupakan pengujian yang mengukur performa daya tegangan arus pada beban win turbin, agar mengetahui performa yang di hasilkan turbin angin tersebut, apakah dengan penambahan variasi wing tip menjadikan energi lebih besar, apakah energi yang di hasilkan lebih optimal, dan apakah energi yang dihasilkan lebih effisien, itulah beberapa pengujian yang akan kita uji.

Prosedur pengujian performa wing tip:

- Pastikan tempat pengujian sudah memenuhi standar pengujian turbin angin, dalam artian hembusan angina yang cukup sehingga turbin angina akan berputar.

- Persiapkan alat pendukung seperti tacho meter sebagai mengukur kecepatan

- Lakukan pengecekan pada blade, pastikan tidak ada sheller yang terlepas yang akan mempengaruhi kinerja turbin angin

- Catat data dan hasil serta dokumentasikan data data tersebut pada saat pengujian

\section{Hasil Data Pengujian}

Dibawah ini merupakan data yang di hasilkan oleh kincir angin, data tersebut di identifikasi dengan alat bantu inverter untuk mengetahui voltase dan amper, sedanfkan rpm di identifikasi menggunakan aplikasi lewat hanphone, berikut data data yg di peroleh antara lain: 
Procedia of Engineering and Life Science Vol. 1. No. 2 Juni 2021

Seminar Nasional \& Call Paper Fakultas Sains dan Teknologi (SENASAINS 2nd)

Universitas Muhammadiyah Sidoarjo

\begin{tabular}{|c|c|c|c|c|}
\hline No & Spesifikasi & Volt & Ampere & Rpm \\
\hline 1. & Tanpa wing tip & 11,2 & 0,14 & 1463 \\
\hline 2. & $\begin{array}{c}\text { Dengan wing tip } \\
\text { lapisan pertama }\end{array}$ & 11,7 & 0,20 & 1395 \\
\hline 3. & $\begin{array}{c}\text { Dengan wing tip } \\
\text { lapisan kedua }\end{array}$ & 11,9 & 0,21 & 1500 \\
\hline
\end{tabular}

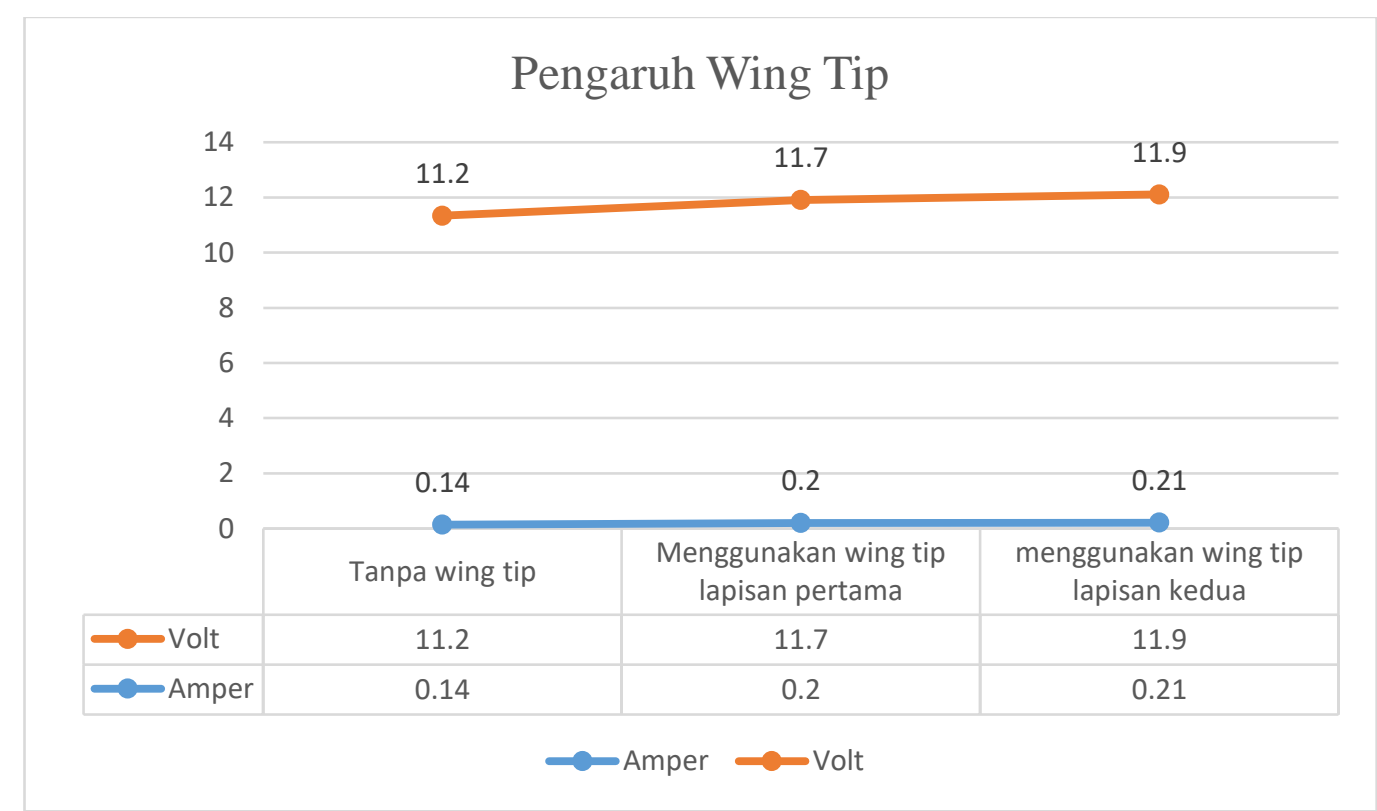

Gravik di atas menjelaskan bahwa energi yang dihasilkan dari beberapa pengujian sangat berbeda beda, pengujian yang pertama tidak menggunakan wing tip mendapatkan energi 11,2 volt dan 0,14 amper, sedangkan pengujian yang ke dua menggunakan wing tip pada lapisan pertama mendapatkan energi 11,7 volt dan 0,20 amper, sedangkan pengujian yang ketiga menggunkan wing tip lapisan kedua mendapatkan energi 11,9 volt dan 0,21 amper

\section{KESIMPULAN}

Dari hasil dan penelitian dan analisa tersebut dapat di simpulkan bahwa perputaran kincir angin tidak begitu kencang jika tidak di beri penambahan wing tip atau di pengaruhi wing tip sehingga energi yang di hasilkanpun juga kecil, berbeda jika kincir angin tersebut di beri penambahan wing tip maka energi yang di hasilkan lebih tinggi di banding tidak menggunakan wing tip, akan tetapi jika di beri tambahan lagi satu lapis dari wing tip yang pertama dan ukuranya lebih besar sedikit dari lapisan yang pertama maka energi yang dihasilkan jauh lebih baik dan sangat besar yg di keluarkan, atau bisa dikatakan jauh lebih optimal.

\section{UCAPAN TERIMA KASIH}

Dan tak lupa juga ucapan terimakasih kepada semua pihak yang telah turut membantu dalam kelancaran pengerjaan pengaruh variasi wing tip

1. Dr Eng Rachmad Firdaus, ST., MT Selaku Dosen Pembimbing Skripsi

2. Wahyu alfiansyah,ST selaku asistensi laboratorium teknik mesin Universitas Muhammadiyah Sidoarjo 


\section{REFERENSI}

[1] ANSYS FLUENT Theory guide, ANSYS, Inc. Release 14.5, Southpointe, October 2012,275 Technology Drive Canonsburg, PA 15317 ANSYS, Inc.

[2] Aresti, L., Tutar, M., Chen, Y., and Calay, R. Computational study of a small scale vertical axis wind turbine (VAWT): Comparative performance of various turbulence models, Wind and Structures, Vol 17, No.6(2013), pp.647-670.

[3] Hartadi, B., \& Maulana, Y. (2017). Optimasi Rancang Bangun Prototype Kincir Air Kapasitas 100 Watt. Al Ulum Sains Dan Teknologi, 3(1), 66-69.

[4] Hidayat, M., \& Wulandari, R. (2018). Unjuk Kerja Turbin Air Kaki Angsa Next-G dengan Variasi Lebar Sudu dan Jumlah Kaki Sudu Menggunakan Pendekatan Komputasional. Jurnal Rekayasa Mesin, 9(2), 99-102.

[5] Kusnadi, Agus Mulyono, Gunawan Pakki, Gunarko, K. (2018). Rancang Bangun Dan Uji Performansi Turbin Air Jenis. Jurnal Teknik Mesin Universitas, 7(2).

[6] Muvariz, M. F., \& Rossbandrio, W. (2015). Studi Gaya Drag dan Lift pada Blade Profile NACA 0018 Turbin Arus Laut Sumbu Vertikal. Jurnal Integrasi, 7(1), 40-44.

[7] Rahmadi, J., Yusuf, I., \& Priyatman, H. (2015). Joni rahmadi 2015. 7(1), 11-18.

[8] Resha, M., \& Yohanes, A. (2019). EFFECT OF AIRFOIL SHAPE ON THE AERODYNAMIC CHARACTERISTICS OF VERTICAL ROTOR WIND TURBINES. 9-10. 